\title{
Corporate Social Responsibility Disclosure by State-Owned Enterprises in Indonesia
}

\author{
Submitted 18/11/19, $1^{\text {st }}$ revision 23/12/19, $2^{\text {nd }}$ revision 07/01/20 accepted 02/02/20
}

\section{Pius Suratman Kartasasmita ${ }^{1}$}

\begin{abstract}
:
Purpose: This article aims to investigate the extent to which State-Owned Enterprises (SOEs) in Indonesia disclose their Corporate Social Responsibility (CSR) programs to the general public.

Design/Methodology/Approach: Quantitative design is used as the main method in the study. Corporate profiling is used for analyzing SOEs profile and program profiling is used to analyze the profile of CSR programs implemented by SOEs.

Findings: The study concludes that, first, SOEs under study disclose their CSR programs to the general public. In terms of indicators it is difficult to conclude that CSR programs disclosed by SOEs signify corporate virtuous citizenship embedding the initial ideas of CSR.

Practical implications: Practical implications of the study are two-folds. First, that SOEs in Indonesia, need to strengthen the institutional drivers of CSR, and put pressure on companies to move beyond philanthropy, rhetoric, legitimization, imagery, and public relations to substantive engagement in CSR and genuine attempts at change and development. Second, the implementation of CSR programs by SOEs is judicially liable to public auditing.

Originality/Value: The value of this study strengthens arguments which hold that the implementation of CSR, even implemented by SOEs, functions more as corporate survival mechanism rather than for solving social and environmental problems.
\end{abstract}

Keywords: Corporate Social Responsibility (CSR), Corporate Virtuous Citizenship (CVC), State-Owned Enterprise (SOEs).

JEL codes: B23, F21, $M$ 41, M48.

Paper Type: research paper.

\section{Acknowledgments:}

This article was written in connection with undergraduate thesis supervision. The author extends his thank to Rembulan Martha Tiassuci for her assistance in collecting data. The initial version of this article was presented before the 1st International Conference on Social and Political Development (ICOSOP) in Medan, 2016. The author would like to thank the Department of Public Administration and LPPM Unpar, for facilitating to conduct research as well as attending the conference.

\footnotetext{
${ }^{l}$ Senior Lecturer at Department of Public Administration and Graduate Program in Development Study. Chair of Centre for Human Development and Social Justice (CHUDS), Parahyangan Catholic University, Bandung, Indonesia. E-mail: pius.gb@unpar.ac.id
} 


\section{Introduction}

Corporations and businesses have been a major influence on society since before the industrial revolution, but academic focus on Corporate Social Responsibility (CSR) is only recently which focuses predominantly on globalized multi-national corporations of the late twentieth century (Caulfield, 2013). It is believed, companies that fail to comply their social responsibility towards workers, customers, society and environment at large will not be able to survive in the long run. Such companies will eventually lose more and more market shares compared with their counterparts which develop a holistic strategy on corporate responsibility (Büchner, 2012).

Within the Indonesian context, the issue of CSR emerged in early 2000s. The issue has attracted public interest, it moved both academics and community activists as well as businesses and governments who are collectively concerned with social inequality and environmental damage. They started to realize the importance of enforcing business ethics and corporate virtuous citizenship. The implementation of CSR is perceived not merely as an ethical responsibility, but ultimately regarded as a juridical obligation. CSR is not a voluntary action, but mandatory by law. Business corporations in Indonesia, either owned by domestic and foreign investors, particularly the State-Owned Enterprises (SOEs), are legally liable to the provisions of Corporate Social Responsibility laws (Sri, 2011).

There are four regulatory frameworks enforcing the implementation of CSR in Indonesia. First, the Ministerial Regulation of the State-Owned Enterprises No. Per05/MB /2007. Second, Laws No. 40 of 2007 regarding the limited liability company. Third, Laws No. 25 of 2007 regarding foreign investment. Fourth, Laws No. 22 of 2001 on Oil and Gas.

Regarding the implementation of CSR by SOEs in Indonesia, there are two different tones. First, an optimism vibe believing SOEs as a critical frontier due to their legal position. Second, a pessimism tone due to the ambiguous roles of SOEs in promoting economic development. It is noted that legally the Government of Indonesia could carry out intervention of market through SOEs using direct funds from the state budget and credit from state banks to participate in building the industrial sector (Roeslan and Zuhdi, 2019), that judicially are subject to be publicly audited.

Regarding the implementation of CSR by private companies, Indonesia has marked impressive legacy in Asia. According to the Channel News Asia Sustainability Ranking 2015, Unilever Indonesia was listed in the 7th of the Top 20 Companies in Asia. This study first of all, aims to investigate the extent to which the SOEs in Indonesia disclose their CSR programs to the general public; as it is indicated that government ownership is proven to be influential towards the level of CSRD (Mohamad Taha, 2009), although it is only partially and inconsistently (Sadou et al., 
2017). Secondly, the study aims to identify whether CSR programs delivered by the SOEs signify Corporate Virtuous Citizenship (CVC).

Three specific research questions are addressed in dealing with the aforementioned purposes. First, what does the profile of SOEs under study look like? Second, to what extent does the SOEs under study provide facilities in governing their CSR programs? Third, what kind of information are disclosed by SOEs to the general public?

\section{Literature Review}

\subsection{Corporate Social Responsibility (CSR)}

The original idea of Corporate Social Responsibility (CSR) was associated with the idea of Corporate Virtuous Citizenship (CVC). As stated by Bowen (2013) who is known as the prominent figure of modern CSR, asserting that the obligation of businessman is to make decision or to follow the line of action which are desirable in term of objectives and values of the society. His idea was strengthened by Kotler (2005) who defines CSR as a commitment to improve community well-being through discretionary business practices and contribution of corporate resources. This notion of CSR is also shared by the World Business Council for Sustainable Development (WBCSD).

Controversies regarding CSR research, however, remain unresolved particularly regarding issues in obtaining detailed information on social activities of companies that have relevance to the public (Sandhu, 2010). The root of controversies can be traced in at least three problems. First, CSR is a multi-dimensional concept. An instrument for measuring CSR may not be comprehensive and accurate. Second, data of CSR used in the study is usually based on self-disclosure reports produced by the company for enhancing investor confidence in the company. Third, most studies focus only on particular CSR areas where the companies are involved. Accordingly, research generalizability is limited. The problems range from defining the concept of CSR to assessing the current knowledge-based CSR (Frederick, 2005). The concept of CSR has been confused, for example, with corporate social performance and corporate citizenship (Mc William, 2006).

Despite the complexity, many studies are crystalized and worth-noting. Firstly, buying behavior is significantly influenced by customer's perception of CSR which relates to ecological reasons, non-discriminative reasons, recycling reasons and communication reasons (Rodrigues and Borges, 2015). Secondly, CSR has impacts on the changes of corporate governance (Cullinan et al., 2016). Thirdly, CSR is important in the formation of corporate identity (Fatma and Rahman, 2014). Finally, CSR has impacted corporate profitability (Xu and Zeng, 2016). Reccently CSR is conceived as a business strategy in maintaining long term corporate profitability. The implications of this view are, first, corporate profitability is a necessary 
condition of social responsibility (Scott, 2007). Second, companies should more closely consider local issues when drawing up CSR policy guidelines in a nonWestern environment (Ozuem et al., 2014). Third, conceptual framework for the corporate citizenship notion implies business and political perspective of corporate citizenship (Camilleri, 2017). All are in the same vibe to conceive CSR as a survival mechanism of business to enhance long term profitability.

Critical perspectives contribute to shape theoretical views of CSR (Banerjee, 2014). Associating corporate citizenship with CSR, is skeptically criticized. In a corporatedominated economy, companies are capable of exploiting market imperfections to gain super normal profits. Their positions are beyond the reach of any existing states. MNCs both in developed and developing countries cannot be controlled by neither government of any countries nor international NGOs. Corporations are significantly powerful entities. It is impractical to expect corporations to be more accountable for a more equitable distribution of their profits to customers and employees through CSR. Critical perspective proposes cooperatives institution as a legitimate alternative to CSR. The cooperative ownership structure automatically creates a fair distribution of surplus and since cooperatives are locally based, hence they are more likely to be both accountable and responsive to local communities (Cato et al., 2007).

\subsection{Corporate Virtuous Citizenship (CVC)}

The concept of CVC is a metaphor of virtuous citizens which refer to individuals who take social role characterized by an orientation towards the social contract, collective responsibility as well as active and positive attitudes toward the state. Therefore, corporate virtuous citizenship by analogy is a social role played by corporations. It is assumed that companies involved in repeated transactions with stakeholders on the basis of trust and cooperation, they are motivated to be honest, trustworthy, and ethical because the returns to such behavior are high. Institutional approaches have also been used to analyze environmental social responsibility (Jones, 1995). The role of institution is essential in shaping the consensus within a firm regarding the establishment of an 'ecologically sustainable' organization (Zanbergen, 1995).

The unresolved question about the future concept of CSR remains 'the extent to which the interests of business in the long run merge with the interests of society' which is differently responded by managerial and academic circles. Managers, on one side, focus on the issue of global corporate citizenship and stakeholder stewardship of what so called as 'profitable responsibility.' They promote 'corporate citizenship' movement as a philanthropic practice which is consistent with 'voluntarism' advocated by governments. This movement embeds in older traditions of corporate social responsibility and responsiveness that fundamentally crafts as an instrumental, self-serving view of the relationship between business and society. On the other side, academics focus more on the study on corporate social 
performance, stakeholder theory, and business ethics approaches, as an accurate descriptor of corporate behavior. It is argued that corporate citizenship movement, actually engages with two conflicting circumstances; rising societal expectations of corporate benefits and promoting value creation in all functions and activities of a firm. Corporate citizenship, therefore, is a two-edged sword to be handled carefully (Windsor, 2001). Such contradiction is not that easy to be resolved.

\subsection{Corporate Social Responsibility Disclosure (CSRD)}

Studies on Corporate Social Responsibility Disclosure (CSRD) cover a wide range of issues. It can be stretched from investigating the benefits of CSRD at international setting (Dhaliwal et al., 2014), to questioning whether CSRD provides incremental value of relevant information to investors (Bowerman and Sharma, 2016). From asserting that CSRD has positive and significant relationship with the exportoriented sector, to exposing a negative impact of the relationship between CSRD and family ownership. Number of firms and industry characteristics are considered as important in determining the extent to which CSRD exists in a developing country (Muttakin and Khan, 2014; Suryanto and Thalassinos, 2017).

Government ownership is proven that influences the level of CSRD (Mohamad Taha, 2009), although it is only partially and inconsistently (Sadou et al., 2017). The significant role of macro structures of CSRD in the form of introduction, initiative, featured initiative, adherence and finance, enable a comprehensive understanding about environmental CSR. While microstructure of CSRD referring to language features of corporate actions and descriptions, enable environmental CSR in a particular time, place and way (Rajandran, 2016).

Conclusions about studies on CSRD, however, are worth-noting. First, it shown that signal breaches from technical trading indicators explains different level of CSRD by firms.

Second, it is questioned whether firms disclose corporate social responsibility information in a genuine attempt to report their impact on society and environment or whether firms use CSRD as a shield to legitimize their business operations (Ling and Sultana, 2015).

Third, it comes up with instruments for measuring CSRD such as disclosure framework index enables cross-sectional and cross-country comparisons over time and the ability to replicate and apply it to other industries or sectors (Jain, Keneley and Thomson, 2015) and CSR disclosure checklist that used to measure the extent of CSRD in the annual reports and to examine the determinants of CSRD using multiple regression (Muttakin and Khan, 2014). Since the implementation of CSR by SOEs normally utilizes public budget allocations, as such public disclosure and public audit are judicially consequential. Given discussed conceptual above, Figure 1 shows logical framework used in this study. 
Figure 1. The Logical Framework and Indicators Used in the Study

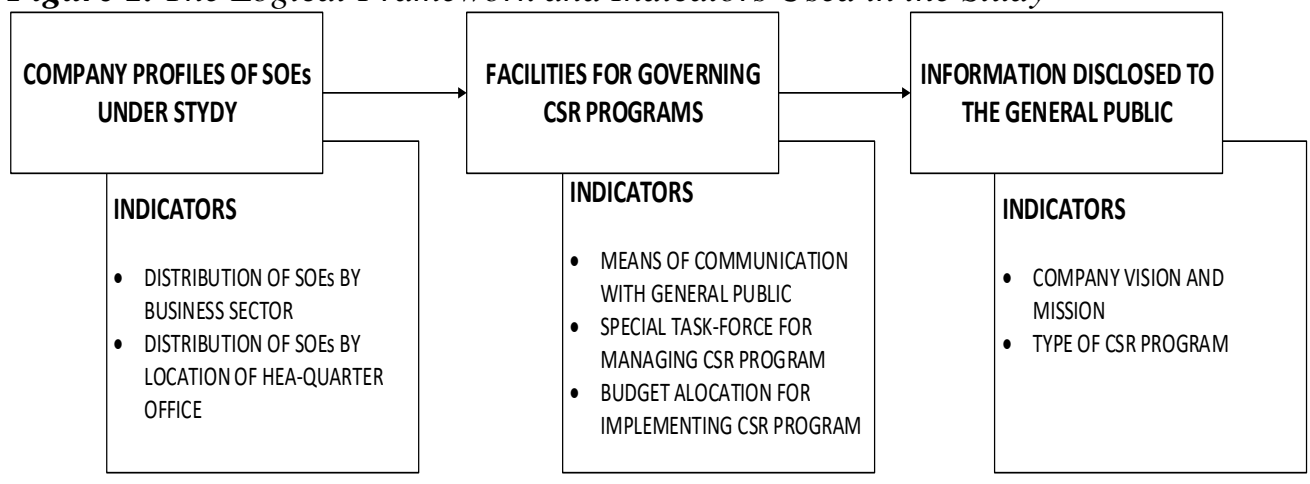

\section{Data and Model}

Quantitative research is employed as the basic research design in this study. As many as 119 SOEs which are in the official list produced by the Indonesian Ministry of SOE 2015 are determined as population and sample. Data collection was limited to the information available in the accessible company website during the period of August-November 2016. Corporate profiling technique is used for constructing and analyzing general profile of SOEs, while program profiling technique was used for constructing and analyzing profile of CSR programs implemented by SOEs under study. Non-parametric descriptive statistic is used to analyze data. The findings are presented in the form of narratives and Tables in order to address the extent to which SOEs in Indonesia disclose their CSR programs to the general public and whether the CSR programs delivered by SOEs in Indonesia signify corporate virtuous citizenship will be confirmed using the discussed literature review.

\section{Results}

\subsection{Company Profiles}

Two indicators the distribution of SOEs by business sector and the distribution of SOEs by location of the head-quarter office, are used to answer the first research question. Assuming that firms and industry characteristics are important in determining the extent to which CSRD (Muttakin and Khan, 2014) including the location of its head-quarter office.

Regarding the business sector of SOEs under study, the 119 SOEs are distributed into thirteen (13) business sectors (Table 1). According to the existing regulation in Indonesia, not all sectors of business are legally enforced to implement CSR programs. Three conceptual reasons can be elicited. First, a socially responsible corporation is one that undertakes its business operations in an efficient and ethical manner. Second, it is an organization that takes an active role in contributing to the well-being of society and behaves in an ecologically friendly way and acts in the 
field of social solidarity. Third, a socially responsible corporation is one that adopts human resources practices that demonstrate respect and concern for the well-being of employees and their families (Ana Patrícia Duarte Carla Mouro José Gonçalves das Neves, 2010). Given the company sectors, it is hard to expect that all SOEs under study would likely to commit with a substantive type of CSR programs. It is more rational to be skeptic that CSR programs disclosed on the company website are gimmicks rather than seriously attempts to deal with social or environmental problems.

Table 1. Numbers, Percentage and Ranking of SOEs by Business Sector

\begin{tabular}{lcl}
\hline Sector of SOEs & Number of SOEs & $\begin{array}{l}\text { Percent } \\
\text { SOEs }\end{array}$ \\
\hline Manufactures & 30 & $25 \%$ \\
Transportation and Storage & 24 & $20 \%$ \\
Finance and Insurance & 20 & $17 \%$ \\
Professional Service, Scientific and Technology & 10 & $8 \%$ \\
Construction & 9 & $8 \%$ \\
Agriculture, Forestry \& Fishery & 7 & $6 \%$ \\
Mining and Drilling & 5 & $4 \%$ \\
Trading and retail & 4 & $3 \%$ \\
Information and Telecommunication & 3 & $3 \%$ \\
Water Supply, Trash Management and Recycle & 2 & $2 \%$ \\
Real Estate & 2 & $2 \%$ \\
Gas, Steam and Cold Air Provider & 2 & $2 \%$ \\
Accommodation, Food and Beverages & 1 & $1 \%$ \\
\hline Total & $\mathbf{1 1 9}$ & $\mathbf{1 0 0 \%}$ \\
\hline
\end{tabular}

Regarding the second indicator, head-quarter office location, $72(60 \%)$ of SOEs under study are located in Jakarta, 40 (34\%) outside Jakarta and $7(6 \%)$ unknown. Jakarta remains the most favorable location to set business offices regardless sector and type of business since Jakarta is accounted for more than $70 \%$ of financial circulation in Indonesia. Further question would be whether Jakarta based companies are kin to engage with CSR programs contributing to solve social and environmental problems than their counterparts located outside Jakarta, or otherwise.

\subsection{Facilities for Governing CSR Programs}

There are three indicators in addressing the second research question. First, whether the company provides mean of communication used for disclosing CSR program. Second, whether the company establishes special taskforce for managing CSR programs. Third, whether the company allocates special budget scheme for financing CSR programs. Regarding the first indicator, findings show that the majority of companies provide sufficient mean of public communications as noted in Table 2. It can be interpreted, that the disclosed CSR programs are known by the general public. The critical question follows is whether this mean of communications is effectively used. 
Table 2. Company Mean of Public Communication

\begin{tabular}{lcl}
\hline Mean of Public Communication & Company & Percent \\
\hline Using e-mail & 97 & $82 \%$ \\
Using website & 115 & $97 \%$ \\
Using telephone & 112 & $94 \%$ \\
\hline
\end{tabular}

As per second indicator of whether the company establishes special taskforce for managing CSR programs, indicates level of seriousness of the company in dealing with CSR programs and predict the magnitude of CSR program running by the company. As it is expected, there is no SOEs under study disclosed the presence of special taskforce for managing CSR within the company. Such finding does not confirm other research using Community Corporate Responsibility Index which concludes, first, that there is an increasing CEO leadership for the corporate responsibility agenda of the firm. Second, governance structures developed over time are now increasingly making use of corporate responsibility committees. In 2002 approximately 15 percent of the firms used a CR committee, the number had increased to more than 60 percent by 2008. Third, firms with a CR committee in place, outperform others in the Corporate Responsibility Index (Spitzeck, 2009) by expanding an important component of corporate strategy and placing it in a global context (Galbreath, 2006). Implication of the finding indicates that SOEs under study do not have substantiate intention in managing CSR programs (Table 3).

Table 3. Company CSR Taskforce

\begin{tabular}{lll}
\hline CSR Taskforce & Company & Percentage \\
\hline Displaying CSR taskforce & 0 & $0 \%$ \\
Displaying no CSR taskforce & 104 & $88 \%$ \\
Website is not accessible & 10 & $8 \%$ \\
Do not have Company Website & 5 & $4 \%$ \\
\hline Total & $\mathbf{1 1 9}$ & $\mathbf{1 0 0 \%}$ \\
\hline
\end{tabular}

Regarding the third indicator, whether the company disclose special budget scheme allocated for CSR programs, reveals with only 14 (12\%) of SOEs under study display CSR budget allocation on the website and the rest of 90 (76\%) display no budget allocation on their website as indicated in Table 4 . This can be interpreted in two ways. First, the majority of SOEs under study do not substantially engage in implementing CSR. Second, SOEs under study do not want to share credential information like budget transparency to the general public for various internal reasons. However, since SOEs use public budget in implementing CSR, public audit is necessary both in terms of programs and budgetary scheme. Despite the fact that the amount of audit fees in Indonesia is a factor determining auditors' judgment in accepting assignments from clients. While a proper amount of fee is proven to have a positive effect on the prevention of fraud (Suryanto, 2014). It is implied that without disclosing budgetary scheme to the general public, the implementation of CSR programs by SOEs under study cannot confirmed as complied with their judicial liability to contribute in solving critical social and environmental issues. 
Instead it might be questioned whether CSRD provides incremental value that only relevant information to investors (Bowerman and Sharma, 2016).

Table 4. CSR Budget on the Company Website

\begin{tabular}{lll}
\hline CSR Budget & Company & Percentage \\
\hline Displaying CSR budget on the website & 14 & $12 \%$ \\
Displaying no CSR budget on the website & 90 & $76 \%$ \\
Website is not accessible & 10 & $8 \%$ \\
Do not have Company Website & 5 & $4 \%$ \\
\hline Total & $\mathbf{1 1 9}$ & $\mathbf{1 0 0 \%}$ \\
\hline
\end{tabular}

\subsection{Type of Information Disclosed}

Two indicators used in dealing with the third research question; whether the company disclose their vision and mission to the general public and whether the company disclose the number and type of CSR program to the general public. As per first indicator, finding is shown in Table 5. At the first glance this result can be interpreted that the majority of SOEs under study are outward-looking companies that might have more concerns and responsiveness towards society problems at large. However, Table 6 shows that only about half $(56 \%)$ of SOEs under study are interested in CSR as their means of implementing the set company vision and mission. It is implied, therefore, that the other half of SOEs under study do not engage with the implementation of CSR as it is judicially mandated for them. Alternatively, they intentionally hide their CSR programs to the general public due to various internal concerns. It is legitimate to skeptically scrutiny the SOEs under study just using CSRD as a shield to legitimize their business operations (Ling and Sultana, 2015).

Table 5. Company Vision and Mission Disclosed by SOEs

\begin{tabular}{lll}
\hline Company Vision and Mission & Website & Percentage \\
\hline Vision and Mission Reflecting Social Concern & 55 & $46 \%$ \\
Vision and Mission Reflecting Internal Concern & 23 & $19 \%$ \\
Vision and Mission is not disclosed on the website & 26 & $22 \%$ \\
Website is not accessible & 10 & $9 \%$ \\
Do not have company website & 5 & $4 \%$ \\
\hline Total & $\mathbf{1 1 9}$ & $\mathbf{1 0 0 \%}$ \\
\hline
\end{tabular}

Table 6. Number of Companies Displaying CSR Program on the Company Website

\begin{tabular}{lll}
\hline CSR Display & Company & Percentage \\
\hline Disclose CSR programs & 67 & $56 \%$ \\
Do not disclose CSR programs & 45 & $38 \%$ \\
Website is not accessible & 2 & $2 \%$ \\
Do not have Website & 5 & $4 \%$ \\
\hline Total & $\mathbf{1 1 9}$ & $\mathbf{1 0 0 \%}$ \\
\hline
\end{tabular}


As the second indicator whether the company disclose the number and type of CSR program to the general public, Table 7 shows that the implemented 172 programs are almost equally distributed into five categories, namely education, health, economy, environment and social. By category, CSR programs disclosed by SOEs under study addresses critical social and environmental issues. However, to substantiate the finding, one should interpret the result in conjunction with the Ministerial Regulation No. Per-05/MBU/2007 as a reference, particularly Article 1(6) regarding the Partnership Program with small businesses and Article 1(7) regarding the Community Development Program.

Regarding the Partnership Program with small businesses, this study cannot conclude whether SOEs under study runs CSR program in order to improve business capacity of small businesses and their independency. Similarly, regarding the Community Development Program, this study cannot come up with the convincing conclusions. There is no evidence to identify activities that empower community members and improve social conditions of society. Some SOEs have allocated some amount of funds for assisting victims of natural disasters, providing educational assistance and/or training, supporting health condition improvement, ensuring the development of infrastructure and/or public utilities, providing religious facilities and supporting nature conservation.

However, it is noted that types of activities conducted are trivial in nature. Charitable type of CSR programs is dominant followed by environmental type of programs, economy, education and surprisingly health at the latest. The programs are more look like philanthropic activities wrapped up within 'corporate citizenship' practicebased movement which is consistent with 'voluntarism' advocated by governments. Such kind of programs are also trivial in nature for not allowing the local community to play a role in the decision-making processes of the company to protect their interests (Mujih, 2007).

Table 7. Type of CSR Program Displayed on the Company Website

\begin{tabular}{|l|l|l|l|}
\hline Field of CSR & $\begin{array}{l}\text { Total } \\
\text { Program }\end{array}$ & Type of Program & Form of Activities \\
\hline Education & 34 & $\begin{array}{l}\text { Education and } \\
\text { Training Program }\end{array}$ & $\begin{array}{l}\text { Familiarizing diseases } \\
\text { Distributing scholarship } \\
\text { Conducting training }\end{array}$ \\
\hline Health & 22 & $\begin{array}{l}\text { Health } \\
\text { Improvement } \\
\text { Programs }\end{array}$ & $\begin{array}{l}\text { Organizing blood donation } \\
\text { Promoting healthy work } \\
\text { Providing free operation } \\
\text { Providing free immunization } \\
\text { Giving "mass circumcision service" }\end{array}$ \\
\hline Economy & 36 & $\begin{array}{l}\text { Poverty } \\
\text { Eradication } \\
\text { Program }\end{array}$ & $\begin{array}{l}\text { Conducting community fair } \\
\text { Establishing piloting village } \\
\text { Facilitating SMEs }\end{array}$ \\
\hline Environment & 39 & $\begin{array}{l}\text { Infrastructure } \\
\text { Improvement }\end{array}$ & $\begin{array}{l}\text { Building religious facilities } \\
\text { Building public sanitation }\end{array}$ \\
\hline
\end{tabular}




\begin{tabular}{|l|l|l|l|} 
& & Program & $\begin{array}{l}\text { Planting trees } \\
\text { Providing garbage facilities } \\
\text { Building public squares } \\
\text { Building roads and bridges }\end{array}$ \\
\hline Social & 41 & $\begin{array}{l}\text { Disaster and other } \\
\text { charity }\end{array}$ & $\begin{array}{l}\text { Delivering staple needs } \\
\text { Providing free fasting break }\end{array}$ \\
\hline Total & $\mathbf{1 7 2}$ & \multicolumn{2}{|l|}{} \\
\hline
\end{tabular}

Similar to the budgetary scheme, CSR programs implemented by SOEs under study are not accountable to general public. This finding implies the emergency call for public audit both in terms of programs and budgetary scheme. Although it is verified that auditors' judgement in Indonesia is determined by amount of fee paid by the clients (Suryanto, 2014) and it is indicated that attitude towards audit judgement are vary across culture. Most people in Central Java who have individualistic culture, for instance, are less supportive to audit judgement compare to people who have collectivistic culture (Suryanto et al., 2019).

\section{Conclusion, Limitations and Avenues for Further Research}

This study concludes that the SOEs under study disclose their CSR programs to the general public. However, in terms of all indicators i.e., business sectors, location of head-quarter office, mean of communication with general public, specific taskforce, as well as budget allocation provided and displayed it is difficult to conclude that the CRS disclosed by the SOEs under study signify corporate virtuous citizenship. None of three criteria used was fulfilled. First, a socially responsible corporation is one that undertakes its business operations in an efficient and ethical manner. Second, it is an organization that takes an active role in contributing to the well-being of the society and behaves in an ecologically friendly way and acts in the field of social solidarity. Third, a socially responsible corporation is one that adopts human resource practices that demonstrate respect and concern for the well-being of employees and their families

This study supports arguments which hold that the implementation of CSRD, even by SOEs, functions more as corporate survival mechanism rather than for solving social and environmental problems. Practical implications of the study are two-folds. First, that SOEs in Indonesia, need to strengthen the institutional drivers of CSR, and put pressure on companies to move beyond philanthropy, rhetoric, legitimization, imagery, and public relations to substantive engagement in CSR and genuine attempts at change and development. Second, the implementation of CSR programs by SOEs need to be audited, although it is verified that most people who have individualistic culture are not supportive to audit judgement, while those who have collectivistic culture are supportive to audit judgement. However, since this study is relaying only on data available on the accessible company website of the listed companies in 2015, it is recommended to further the study using the most recent data and more comprehensive methods. 


\section{References:}

Ana Patrícia Duarte Carla Mouro José Gonçalves das Neves. 2010. Corporate social responsibility: mapping its social meaning. Management Research: Journal of the Iberoamerican Academy of Management, 8(2), 101-122.

Banerjee, S.B. 2014. A critical perspective on corporate social responsibility. Critical Perspectives on International Business, 10(1/2), 84-95.

Bowerman, S., Sharma, U. 2016. The effect of corporate social responsibility disclosures on share prices in Japan and the UK. Corporate Ownership and Control, 13(2CONT1).

Büchner, L.M. 2012. Corporate Social Responsibility and Sustainability from a Global, European and Corporate Perspective. Corporate Social Responsibility and Sustainable Governance. Eurolimes, 13, 41-55.

Camilleri, M.A. 2017. Corporate citizenship and social responsibility policies in the United States of America. Sustainability Accounting, Management and Policy Journal, 8(1), 77-93. https://doi.org/10.1108/SAMPJ-05-2016-0023.

Cato, C.A., et al. 2007. Corporate Social Responsibility in Your Own Backyard. Journal of Social Responsibility, 37.

Caulfield, P.A. 2013. The evolution of strategic corporate social responsibility. Journal of Business Research, 8(3), 220-242. https://doi.org/10.1108/EMJB-05-2013-0030.

Cullinan, C.P., Mahoney, L.S., Roush, P. 2016. Corporate social responsibility and shareholder support for corporate governance changes. Social Responsibility Journal, 12(4), 687-705. https://doi.org/10.1108/SRJ-10-2015-0161.

Dhaliwal, D., Li, O.Z., Tsang, A., Yang, Y.G. 2014. Corporate social responsibility disclosure and the cost of equity capital: The roles of stakeholder orientation and financial transparency. Journal of Accounting and Public Policy, 33(4).

Fatma, M., Rahman, Z. 2014. Building a corporate identity using corporate social responsibility: a website based study of Indian banks. Social Responsibility Journal, 10(4), 591-601. https://doi.org/10.1108/SRJ-01-2013-0002.

Frederick, R. 2005. Corporate Social Responsibility and Corporate Citizenship: Towards Corporate Accountability. Journal of Business and Society Review, 191-212.

Galbreath, J. 2006. Corporate social responsibility strategy: strategic options, global considerations. Corporate Governance: The International Journal of Business in Society, 6(2), 175-187. https://doi.org/10.1108/14720700610655178.

Jain, A., Keneley, M., Thomson, D. 2015. Voluntary CSR disclosure works! Evidence from Asia-Pacific banks. Social Responsibility Journal, 11(1).

Jamali, D. 2014. Corporate Social Responsibility and Sustainability: Emerging Trends in Developing Economies.

Kotler, P. 2005. Corporate Social Responsibility: Doing the Most Good for Your Company and Your Cause. Wiley.

Ling, T.C., Sultana, N. 2015. Corporate social responsibility: what motivates management to disclose? Social Responsibility Journal, 11(3), 513-534.

Mc William, S.A. 2006. Guest Editor Introduction Corporate Social Responsibility: Strategic Implications. Journal of Management Studies, 2-8.

Mohamad Taha, M.H. 2009. The relationship between corporate social responsibility disclosure and corporate governance characteristics in Malaysian public listed companies. Social Responsibility Journal, 5(2), 212-226.

Mujih, E. 2007. Implementing Corporate Social Responsibility: Punishment or Compliance? Social Responsibility Journal, 3(3), 79-85.

Muttakin, M.B., Khan, A. 2014. Determinants of corporate social disclosure: Empirical 
evidence from Bangladesh. Advances in Accounting, 30(1).

https://doi.org/10.1016/j.adiac.2014.03.005.

Ozuem, W., Howell, K., Lancaster, G. 2014. Corporate social responsibility: towards a context-specific perspective in developing countries. Social Responsibility Journal, 10(3), 399-415. https://doi.org/10.1108/SRJ-04-2012-0086.

Rajandran, K. 2016. Corporate involvement brings environmental improvement: The language of disclosure in Malaysian CSR reports. Social Responsibility Journal, 12(1).

Rodrigues, P., Borges, A.P. 2015. Corporate social responsibility and its impact in consumer decision-making. Social Responsibility Journal, 11(4).

Roeslan, F., Zuhdi, S. 2019. From Inward Looking to Outward Looking: Dynamics of Indonesian Economic Policy during the New Order Era. Proceeding of The 13th International Conference OnMalaysia-Indonesia Relations (PAHMI), 21-26.

Sadou, A., Alom, F., Laluddin, H. 2017. Corporate social responsibility disclosures in Malaysia: evidence from large companies. Social Responsibility Journal, 13(1).

Sandhu, H.A. 2010. Corporate Social Responsibility Initiaives: an Analysis of Voluntary Corporate Disclosure. South Asian Journal of Management, 47.

Scott, S. 2007. Corporate Social Responsibility and the Fetter of Profitability. Journal of Social Responsibility.

Spitzeck, H. 2009. The development of governance structures for corporate responsibility. Corporate Governance, 9(4), 495-505. https://doi.org/10.1108/14720700910985034.

Sri, Y. 2011. Corporate Social Responsibility (CSR): Public Accountability of Business Sector and its Implementation on the Study of Public Administration. Journal of Spirit Public, 15.

Suryanto, T. 2014. Determinants of Audit Fee Based on Client Attribute, Auditor Attribute, and Engagement Attribute to Control Risks and Prevent Fraud : A Study on Public Accounting Firms in Sumatra-Indonessia. International Journal of economics and Business Administration, 2(3), 27-39. DOI: 10.35808/ijeba/46.

Suryanto, T., Thalassinos, I.E. 2017. Cultural Ethics and Consequences in Whistle-Blowing among Professional Accountants: An Empirical Analysis. Journal of Applied Economic Sciences, 6(52), 1725-1731.

Suryanto, T., Thaib, D., Muliyati, M. 2019. Individualism and Collectivism Culture to Audit Judgement. International Journal of Economics and Business Administration, 7(2), 2638. DOI: $10.35808 / \mathrm{ijeba} / 212$.

Wernerfelt, B. 1984. A resources based view of the firm. Strategic Management Journal, 171-180.

Windsor, D. 2001. The Future of Corporate Social Responsibility. The International Journal of Organization Analysis, 225-238.

Xu, B., Zeng, T. 2016. Profitability, state ownership, tax reporting and corporate social responsibility: evidence from Chinese listed firms. Social Responsibility Journal, 12(1). https://doi.org/10.1108/SRJ-06-2014-0076.

Zanbergen. 1995. Ecologically sustainable organization: an institutional approach. Academy of Management Review, 1015-1052. 